\title{
MODIFICATIONS OF NITRIC OXIDE PRODUCTION IN RAT TISSUES BY ELLAGIC ACID, IPRIFLAVONE AND RESVERATROL: A COMPARATIVE STUDY
}

\author{
Maija Dzintare, Larisa Baumane, Dainuvīte Meirena, Jeḷena Šaripova, \\ Lāsma L,auberte, Ivars Kalviņš, and Nikolajs Sjakste \\ Latvian Institute of Organic Synthesis, Aizkraukles iela 21, Rīga, LV-1006, LATVIA \\ E-mail: maija.dzintare@gmail.com
}

Contributed by Nikolajs Sjakste

\begin{abstract}
When administered as drugs or consumed as food components, polyphenolic compounds synthesised in plants interfere with intracellular signal transduction pathways, including pathways of nitric oxide (NO) synthase (NOS) expression. However, the effects of these compounds in vivo do not always correlate with NOS-inhibiting activities, as revealed in experiments with cultured cells. The goal of this work was to compare the effects of resveratrol, ellagic acid and ipriflavone on NO production in rat organs measured by means of ESR spectroscopy. All of the above compounds are known as inhibitors of iNOS expression. The presumed ability to decrease NO production was manifested only by ellagic acid; it decreased NO production in spleen of intact rats. Iproflavone and resveratrol even enhanced the lipopolyssacharides (LPS)-induced increase of NO production. Ipriflavone increased NO production in the brain cortex, cerebellum, liver, heart, kidneys, blood, lungs and skeletal muscles. Resveratrol produced a similar effect in all of the above organs, except kidneys, lungs and muscles. Taken together, our results suggest that modifications of NO level in tissues by a natural compound cannot be predicted from data about its effects on NOS expression or activity. This stresses the importance of direct measurements of NO in tissues.
\end{abstract}

Key words: nitric oxide, resveratrol, ellagic acid, ipriflavone, EPR spectroscopy.

\section{INTRODUCTION}

Natural biologically active compounds of plant origin including flavonoids, are the widest marketed groups of dietary supplement, besides vitamins and minerals. Some of them are used as drugs. Many plant derived compounds manifest antioxidant, anti-inflammatory, anti-oestrogenic, anti-mutagenic and anticarcinogenic effects (Ferguson, 2001; Sarkar and Li, 2004). These substances are known to influence also nitric oxide enzymatic production and stability of the radical (Olszanecki et al., 2002). It is supposed that flavanoid intake influences mortality from nitric oxidedependent processes: ischemic heart disease, stroke, diabetes mellitus, and cancer (Bayard et al., 2007). This implies significance of uptake of flavonoid and other natural compounds for functions of cardiovascular, immune and nervous systems. Impact of a given compound on NO production is usually deduced from in vitro NOS expression and nitrite production. However, modification of NO synthesis by drugs in animals and humans appears to be complicated and dependent of numerous factors. For example, halogenated volatile anaesthetics suppress NO neurotransmitter function, while the same time the same anaesthetics produce vasodilatation via increased NO production. These anaesthetics inhibit nNOS activity in the cerebellum, while they stimulate iNOS activity in brain cortex and appear to be very weak NOS inhibitors in vitro (Sjakste et al., 1999; Сьяксте и др., 2001; Sjakste et al., 2005). In our opinion, only direct measurement of NO production in vivo can reveal the NO-dependent effects of a given drug. The goal of this work was to monitor modification of NO production in rat organs by several natural compounds: flavonoids ellagic acid and ipriflavone and stilbene resveratrol. Chemical structures of the compounds are given in Figure 1.

Resveratrol is a phytoalexin produced naturally by several plants when under attack by pathogens such as bacteria or fungi. Resveratrol is found in the skin of red grapes and is a constituent of red wine. This stilbene is considered to be main biologically active substance of red wine (Birrell et al., 2005). The compound can induce vasorelaxation by NO-dependent mechanisms (Chen and Pace-Asciak, 1996) and increase eNOS expression (Hsieh et al., 1999; Wallerath et al., 2005). Resveratrol inhibits the NFk-B pathway and attenuates liposaccharide (LPS) effects (Manna et al., 2000; Birrel et al., 2005). It protects neurons 


\section{Resveratrol}<smiles>Oc1ccc(/C=C/c2cc(O)cc(O)c2)cc1</smiles>

Ipriflavone<smiles>CC(C)Oc1ccc2c(=O)c(-c3ccccc3)coc2c1</smiles>

Ellagic acid

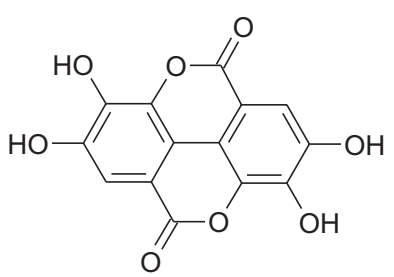

Fig 1. Chemical structures of resveratrol, ellagic acid, and iproflavone.

against NO toxicity (Bastianetto et al., 2000) and scavenges NO (Cíz et al., 2008).

Ellagic acid is a powerful, polyphenolic antioxidant found in certain plants and fruits such as pomegranates and raspberries. Ellagic acid suppresses the release of NO from cultured cells stimulated to express iNOS (Soliman and Mazzio, 1998; Akubue and Stohs, 1992).

Ipriflavone is a synthetic isoflavone, which is used to inhibit bone resorption, maintain bone density and to prevent osteoporosis in postmenopausal women. Ipriflavone inhibits LPS-induced NO release (Koncz and Horváth, 1996).

Taken together these data indicate that all the above compounds should decrease LPS-induced NO production in vivo, and that resveratrol appears to be capable of increasing NO production. No data about modification of NO produc- tion by these compounds is available. Thus, our study was aimed to fill a significant gap in knowledge about the biological activities of natural compounds.

\section{MATERIALS AND METHODS}

Natural compounds. Resveratrol, ellagic acid and iproflavone were purchased from Dayang Chemical Co., LTD (Taiwan).

Chemicals. Lipopolysaccharide, diethylthiocarbamate, ferrous sulfate, sodium citrate and all other chemicals were from Sigma-Aldrich Chemie GmbH (Taufkirchen, Germany).

Experiment design and drug administration. Animals were obtained from the Laboratory of Experimental Animals, Rīga Stradiňš University, Latvia. All experimental procedures were carried out in accordance with guidelines of the Directive 86/609/EEC "European Convention for the Protection of Vertebrate Animals Used for Experimental and other Scientific Purposes" (1986) and were approved by the Animal Ethics Committee of the Food and Veterinary Service (Rīga, Latvia).

Wistar male rats were used in experiments, each weighing $215.00 \pm 5.63 \mathrm{~g}$ at the beginning of experiment. The environment was maintained at a temperature of $22 \pm 0.5{ }^{\circ} \mathrm{C}$ with a 12-h light/dark cycle. Animals were fed a standard laboratory diet. Rats were assigned to the following experimental groups (Table 1). Group $1(n=24)$ served as a control for NO detection experiments. 30 minutes after spin trap injection rats were decapitated under slight ether anaesthesia. In Groups 2 and 3 resveratrol and ellagic acid correspondingly were administered per os in dose $50 \mathrm{mg} / \mathrm{kg}$. At

Table 1

EFFECT OF RESVERATROL, ELLAGIC ACID AND IPROFLAVONE ON NO CONCENTRATION IN DIFFERENT RAT ORGANS AND TISSUES IN INTACT RATS AND UNDER LIPOPOLISACCHARIDE-INDUCED INFLAMMATION

\begin{tabular}{|c|c|c|c|c|c|c|c|c|c|c|}
\hline Groups\Organs & Cortex & Cerebellum & Liver & Heart & Kidney & Testes & Blood & Lungs & Spleen & Muscle \\
\hline 1 Control, $n=24$ & $57.0 \pm 3.8$ & $22.4 \pm 1.9$ & $57.5 \pm 7.6$ & $2.0 \pm 0.9$ & $8.4 \pm 1.5$ & $11.7 \pm 1.4$ & $59.8 \pm 6.1$ & $68.5 \pm 5.4$ & $71.5 \pm 12.6$ & $15.7 \pm 1.8$ \\
\hline $\begin{array}{c}2 \text { Resveratrol (50 } \\
\mathrm{mg} / \mathrm{kg})\end{array}$ & $85.7 \pm 20.0$ & $21.5 \pm 3.6$ & $73.8 \pm 21.7$ & $3.4 \pm 1.2$ & $6.0 \pm 0.6$ & $12.0 \pm 1.6$ & $74.2 \pm 5.7$ & $72.0 \pm 9.7$ & $72.8 \pm 20.8$ & $11.9 \pm 5.4$ \\
\hline $\begin{array}{c}3 \text { Ellagic acid (50 } \\
\mathrm{mg} / \mathrm{kg}) \mathrm{n}=8\end{array}$ & $47.2 \pm 7.5$ & $21.5 \pm 4.0$ & $65.2 \pm 16.9$ & $0.9 \pm 0.4$ & $6.6 \pm 3.4$ & $9.8 \pm 3.2$ & $46.2 \pm 8.3$ & $70.7 \pm 17.7$ & $33.3 \pm 5.2 *$ & $13.9 \pm 2.6$ \\
\hline $\begin{array}{c}\text { LPS }(10 \\
\mathrm{mg} / \mathrm{kg}), \mathrm{n}=28\end{array}$ & $172.2 \pm 13.3$ & $147.7 \pm 21.7$ & $\begin{array}{c}1434.3 \pm \\
104.7\end{array}$ & $287.6 \pm 21.7$ & $356.5 \pm 29.9$ & $102.5 \pm 20.9$ & $380.4 \pm 33.4$ & $919.6 \pm 64.7$ & $\begin{array}{c}1061.6 \pm \\
83.3\end{array}$ & $140.2 \pm 15.4$ \\
\hline $\begin{array}{c}5 \text { Resveratrol (50 } \\
\mathrm{mg} / \mathrm{kg})+\mathrm{LPS} \\
(10 \mathrm{mg} / \mathrm{kg}) \\
\mathrm{n}=9\end{array}$ & $\begin{array}{l}376.4 \pm \\
63.6^{* *}\end{array}$ & $\begin{array}{l}361.6 \pm \\
73.3 * *\end{array}$ & $\begin{array}{l}2968.0 \pm \\
555.4 * *\end{array}$ & $\begin{array}{l}571.4 \pm \\
113.6^{* *}\end{array}$ & $\begin{array}{c}729.4 \pm \\
184.7\end{array}$ & $144.2 \pm 47.0$ & $\begin{array}{l}622.2 \pm \\
105.6 * *\end{array}$ & $\begin{array}{c}1405.2 \pm \\
335.7\end{array}$ & $\begin{array}{l}2658.0 \pm \\
462.8 * *\end{array}$ & $300.2 \pm 92.7$ \\
\hline $\begin{array}{c}5 \text { Ellagic acid (50 } \\
\mathrm{mg} / \mathrm{kg})+\mathrm{LPS} \\
(10 \mathrm{mg} / \mathrm{kg}) \\
\mathrm{n}=10\end{array}$ & $290.8 \pm 73.3$ & $239.0 \pm 96.6$ & $\begin{array}{c}1865.2 \pm \\
458.3\end{array}$ & $284,8 \pm 61.2$ & $\begin{array}{c}402.3 \pm \\
111,8\end{array}$ & $97.6 \pm 19.6$ & $439.0 \pm 69.5$ & $\begin{array}{c}943.2 \pm \\
185.8\end{array}$ & $\begin{array}{c}1324.8 \pm \\
166,8\end{array}$ & $192.6 \pm 51.5$ \\
\hline $\begin{array}{c}5 \text { Ipriflavone (50 } \\
\mathrm{mg} / \mathrm{kg})+\mathrm{LPS} \\
(10 \mathrm{mg} / \mathrm{kg}) \\
\mathrm{n}=6\end{array}$ & $\begin{array}{l}334.2 \pm \\
58.3^{* *}\end{array}$ & $\begin{array}{l}289.2 \pm \\
49.3 * *\end{array}$ & $\begin{array}{l}2406.7 \pm \\
430.3 * *\end{array}$ & $\begin{array}{l}487.0 \pm \\
63.1 * *\end{array}$ & $\begin{array}{l}590.7 \pm \\
75.8 * *\end{array}$ & $134.8 \pm 25.0$ & $\begin{array}{l}814.7 \pm \\
68.0 * *\end{array}$ & $\begin{array}{l}1406.5 \pm \\
164.1 * *\end{array}$ & $\begin{array}{l}2164.7 \pm \\
402.4 * *\end{array}$ & $\begin{array}{l}297.7 \pm \\
43.5 * *\end{array}$ \\
\hline
\end{tabular}


3.5 hours after substance administration, spin trap was injected, and after $30 \mathrm{~min}$ rats were decapitated under slight ether anaesthesia. In Group $4(n=28)$, rats were intraperitoneally injected lipopolysaccharide $(10 \mathrm{mg} / \mathrm{kg})$, spin traps (Kleschyov et al., 2007) were administered 3.5 hours later; 30 minutes after spin trap injection rats were decapitated under slight ether anaesthesia. In Groups 5-7 rats were intraperitoneally injected lipopolysaccharide $(10 \mathrm{mg} / \mathrm{kg})$, resveratrol, ellagic acid and ipriflavone correspondingly in dose $50 \mathrm{mg} / \mathrm{kg}$ administered per os at the same time, spin traps were administered 3.5 hours later, and 30 minutes after spin trap injection rats were decapitated under slight ether anaesthesia.

Administration of spin trap agents. To determine the nitric oxide content in the tissues we used the protocol originally elaborated by A.L. Kleschyov and A. F. Vanin (reviewed in Kleschyov et al., 2007). Spin traps were administered 30 minutes before the sacrifice. Rats were administered 400 $\mathrm{mg} / \mathrm{kg}$ of the nitric oxide scavenger diethylthiocarbamate via intraperitoneal injection and ferrous citrate subcutaneously $(40 \mathrm{mg} / \mathrm{kg}$ ferrous sulphate $+200 \mathrm{mg} / \mathrm{kg}$ sodium citrate). Diethylthiocarbamate and ferrous citrate form a complex that traps nitric oxide and forms a paramagnetic $\mathrm{Fe}-$ diethylthiocarbamate - nitric oxide complex $\left[\mathrm{Fe}(\mathrm{DETC})_{2}{ }^{-}\right.$ $\mathrm{NO}$, which is easily detected by ESR (electron spin resonance spectroscopy) spectroscopy.

Sacrifice, organ dissection and sample preparation for electron paramagnetic resonance spectroscopy. Following the drug and spin trap administration rat were decapitated under slight ether anaesthesia, samples of brain cortex, cerebellum, myocardium tissue, liver, kidney, testes, skeletal muscles, lungs and blood were compacted in a glass tube $30 \mathrm{~mm}$ in length with inner diameter $4 \mathrm{~mm}$ and immediately frozen in liquid nitrogen. Before recording the ESR spectra, the specimen was placed in a quartz finger Dewar flask ER 167 FDS-Q (Bruker, Karlsruhe, Germany) filled with liquid nitrogen.

ESR measurements. ESR spectra were recorded in liquid nitrogen using an ESR spectrometer "Radiopan" SE/X2544 (Radiopan, Poznan, Poland). Conditions of electron paramagnetic resonance measurements were: operation at $\mathrm{X}$-band, $25 \mathrm{~mW}$ microwave power, $100 \mathrm{kHz}$ modulation frequency, $5 \mathrm{G}$ modulation amplitude, receiver gain $0.5 \times$ $10^{4}$, and time constant $1 \mathrm{~s}$. Spectra were recorded for $4 \mathrm{~min}-$ utes. The nitric oxide content in the samples was evaluated from the height of the third component of the NO signal at $\mathrm{g}=2.031$.

The NO concentration (ng/g of tissue) was calculated on the basis of calibration curves as described previously. Briefly, different quantities of $\mathrm{NaNO}_{2}$ (final concentrations 10, 20, $30,40,60,100 \mathrm{mM})$ were mixed with DETC $(33 \mathrm{mg} / \mathrm{ml})$ and $\mathrm{FeSO}_{4} \cdot 7 \mathrm{H}_{2} \mathrm{O}(3.3 \mathrm{mM})$, and an excess of $\mathrm{Na}_{2} \mathrm{~S}_{2} \mathrm{O}_{4}(2$ $\mathrm{M})$ was added to the mixture. The EPR spectra were taken as described above. Further details are given in our previous publications (Sjakste et al., 1999; Baumane et al., 2002; Sjakste et al., 2004; 2005; 2007).
Statistical analysis. Results were expressed as mean \pm SD. Significance of differences in NO concentration and iNOS expression between groups was evaluated by the Student's unpaired $t$-test.

\section{RESULTS}

Background level of NO production in rat organs and its modification by natural compounds. In order to test the ability of the flavonoids to modify NO production in animals, the radical concentration was monitored in several rat organs and tissues. Data are summarised in Table 1. To determine the background NO levels in rat organs, rats were injected with DETC and ferrous citrate, and sacrificed 30 min later. EPR spectra of the different organs had a typical $\mathrm{Cu}-\mathrm{DETC}$ spectrum shape with a superposed Fe(DETC) ${ }_{2}-$ NO peak. Representative spectra are given in Fig. 2. The NO contents were determined in brain cortex, cerebellum,

A
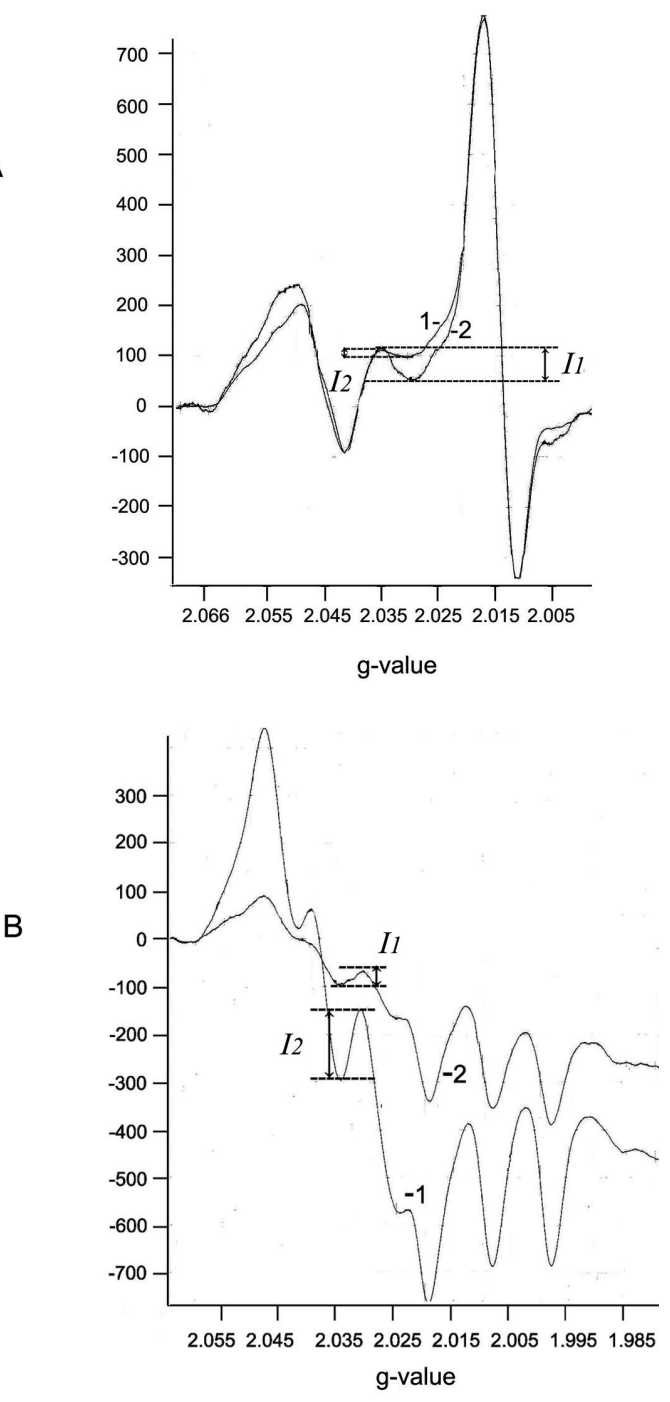

Fig 2. Electron paramagnetic resonance spin trapping of NO in rat organs. A - spleen; 1 - control animals; 2 - rats treated with ellagic acid. B blood; 1 - LPS-treated rats (10 mg/kg, 4 hours); 2 - ipriflavone (50 $\mathrm{mg} / \mathrm{kg}$ ) was administered simultaneously with LPS.

$I_{1}$ and $I_{2}$ - intensity of the third component of the NO spectrum for curves 1 and 2, correspondingly. Representative EPR spectra of three experiments. 
liver, heart, kidneys, testes, blood, lungs, spleen and muscles (not in all of above organs in some experiment series) with the highest NO levels in the cortex, cerebellum, liver, lungs, muscles and blood (Table 1). NO contents in heart, kidneys and testes were lower by an order of magnitude. In intact animals ellagic acid provoked some decrease of NO production in the spleen; resveratrol did not influence the process in any organ (Table 1).

Effects of resveratrol, ellagic acid and ipriflavone on NO production in LPS-treated rats. In the following set of experiments, the activity of the studied compounds as modifiers of NO production was tested against the background of the iNOS induction. Intraperitoneal injection of LPS to the animals caused a drastic increase of NO levels in all tissues studied (Table 1). The highest accumulation of nitric oxide was detected in liver, whereas very strong increases in nitric oxide accumulation (50-100-fold compared to control) were observed in heart, blood and kidney. However, the effects of LPS were less pronounced in brain tissues, where nitric oxide increased 4-6 times only. The nitric oxide increase in testes was at a comparable magnitude.

In LPS-treated animals, ipriflavone increased NO production in the brain cortex, cerebellum, liver, heart, kidneys, blood, lungs and skeletal muscles. Resveratrol produced a similar effect in all of above organs, except kidneys, lungs and muscles (Table 1). Ellagic acid did not modify the LPS-induced outburst of NO synthesis. Thus, natural compounds produce measurable effects on NO production; however, we did not observe NO-decreasing effects.

\section{DISCUSSION}

In our experiments resveratrol enhanced LPS-triggered NO production in the brain cortex, cerebellum, liver, heart, blood and spleen. Some literature data support our findings. Resveratrol can induce vasorelaxation by both NO-dependent and NO-independent mechanisms (Chen and PaceAsciak, 1996). It increases NO production in hypertensive rats (Liu et al., 2005). These effects indicate possible increase of NO production by resveratrol at least in endothelial cells; this hypothesis has been validated in experiments with endothelial cell culture and rat aorta: resveratrol increased eNOS expression (Hsieh et al., 1999; Wallerath et $a l ., 2005)$. There are data demonstrating that the characteristic endothelium-dependent vasorelaxant effect of resveratrol in rat aorta seems to be caused by the inhibition of vascular NADH/NADPH oxidase and the subsequent decrease of basal cellular superoxide radical generation and, therefore, of NO biotransformation (Oralla et al., 2002). However, resveratrol inhibits the NFK-B pathway and attenuates LPS effects (Birrel et al., 2005; Manna et al., 2000). Other authors report that resveratrol posttranscriptionally decreases LPS-induced nitrite release. It increases basal levels of TNF- $\alpha$ mRNA and protein and enhances LPS-induced TNF- $\alpha$ mRNA and cytokine release. This indicates that the resveratrol does not inhibit LPS-induced NF-kB activation, but instead has a more selective action on genes activated by LPS (Wadsworth, Koop, 1999). It protects neurons against NO toxicity (Bastianetto et al., 2000) and scavenges NO (Cíz et al., 2008). Apparently, the latter effects of resveratrol do not produce a measurable impact on NO production in animals.

In our experiments, ellagic acid increased NO production in the spleen of intact animals. This contradicts published data about the impact of the ellagic acid on NO production. Ellagic acid suppresses the release of NO from lipopolysaccharide (LPS)/gamma-interferon (IFN-gamma) stimulated C6 astrocyte cells (Soliman and Mazzio, 1998) and decreases endrin-induced NO release by peritoneal macrophages (Akubue and Stohs, 1992). We suppose the existence of NO-protecting effects of the substance; its antioxidant activity (Girish and Pradhan, 2008) validates this hypothesis. The ability of the compound to increase NO production in some organs could be ascribed to antioxidant activity of the substance (Singh et al., 2008). Scavenging of reactive oxygen species prevents involvement of NO in interaction with these radicals, increasing its bioavailability. This effect is produced by several natural compounds, including cocoa polyphenols (Sies et al., 2005) and resveratrol (Orallo et al., 2002).

Despite the fact that ipriflavone inhibits LPS-induced NO release from RAW-264.7 cells, but its metabolite 7-isopropoxy-3-(4-hydroxyphenyl)-4H-1-benzopyran-4-one appears to be a much more potent inhibitor (Koncz and Horváth, 1996), we did not observe any NO-decreasing activity of the compound. In contrast, it enhanced NO production in many organs of LPS-treated animals. In this case, the COX-inhibiting activity of the drug (Seaver and Smith, 2004) aimed on decrease of inflammatory effects could increase bioavailability of NO.

Taken together our results suggest that modifications of NO level in tissues by a natural compound cannot be predicted from data about its effects on NOS expression or activity. Moreover, it seems that iNOS expression is not a limiting factor for NO production in the LPS model used in this study. Discrepancies in the data can arise for several reasons. Despite the ability of a compound to inhibit iNOS expression, demonstrable in cell culture systems, this activity cam be obscured by another effect of the compound, its antioxidant activity for example. In this case, scavenging of a reactive oxygen species prevents involvement of $\mathrm{NO}$ in interaction with these radicals, and NO concentration can increase despite its limited production (Orallo et al., 2002; Sies et al., 2005). Capability of a compound to increase NOS expression or activity in vitro can be also attenuated on the organism level. Recent findings indicate the possibility of feedback control of NOS activity (Salerno and Ghosh, 2009). In this case, increased excessively produced NO would inhibit NOS activity and the measured NO level in the tissues could be unchanged or even increased. It should be kept in mind that mainly the level of produced NO radical influences physiological processes in tissues. To our opinion, recommendations about the use of a natural compound as a drug with a NO-modifying activity should be 
based on direct measurements of NO in the tissues after administration of a given compound.

\section{ACKNOWLEDGEMENTS}

This study was supported in part by the National Research Programme 2010.10.-4/VPP4, ,Creation of novel means and methods for prophylaxis, treatment and diagnostics, elaboration of biomedical technologies for improvement of social health“ and grant 04.1317 „Pathological production of nitric oxide, possibilities of its pharmacological correction" awarded to N. Sjakste by the Latvian Council of Science.

\section{REFERENCES}

Akubue, P.I., Stohs, S.J. (1992). Endrin-induced production of nitric oxide by rat peritoneal macrophages. Toxicol Lett., 62(2-3), 311-316.

Bastianetto, S., Zheng, W.H., Quirion, R. (2000). Neuroprotective abilities of resveratrol and other red wine constituents against nitric oxide-related toxicity in cultured hippocampal neurons. Brit. J. Pharmacol., 131(4), $711-720$.

Baumane, L., Dzintare, M., Zvejniece, L., Meirena, D., Lauberte, L., Sile, V., Kalvinsh, I., Sjakste, N. (2002). Increased synthesis of nitric oxide in rat brain cortex due to halogenated volatile anesthetics confirmed by EPR spectroscopy. Acta Anaesthesiol Scand., 46, 378-383.

Bayard, V., Chamorro, F., Motta, J., Hollenberg, N.K. (2007). Does flavanol intake influence mortality from nitric oxide-dependent processes? Ischemic heart disease, stroke, diabetes mellitus, and cancer in Panama. Int. J. Med. Sci., 4(1), 53-58.

Birrell, M.A., McCluskie, K., Wong, S., Donnelly, L.E., Barnes, P.J., Belvisi, M.G. (2005). Resveratrol, an extract of red wine, inhibits lipopolysaccharide induced airway neutrophilia and inflammatory mediators through an NF-kappaB-independent mechanism. FASEB J., 19(7), $840-841$

Chen, C.K., Pace-Asciak, C.R. (1996). Vasorelaxing activity of resveratrol and quercetin in isolated rat aorta. Gen. Pharmacol., 27(2), 363-366.

Cíz, M., Pavelkovị, M., Gallovị, L., Krịlovị, J., Kubala, L., Lojek, A. (2008). The influence of wine polyphenols on reactive oxygen and nitrogen species production by murine macrophages RAW 264.7. Physiol. Res., 57(3), 393-402.

Ferguson, L.R. (2001). Role of plant polyphenols in genomic stability. Mutat Res., 475(1-2), 89-111.

Girish, C., Pradhan, S.C. (2008). Drug development for liver diseases: Focus on picroliv, ellagic acid and curcumin. Fundam. Clin. Pharmacol., 22(6), $623-632$

Hsieh, T.C., Juan, G., Darzynkiewicz, Z., Wu, J.M. (1999). Resveratrol increases nitric oxide synthase, induces accumulation of p53 and p21(WAF1/CIP1), and suppresses cultured bovine pulmonary artery endothelial cell proliferation by perturbing progression through $\mathrm{S}$ and G2. Cancer Res., 59(11), 2596-2601.

Kleschyov, A.L., Wenzel, P., Munzel, T. (2007). Electron paramagnetic resonance (EPR) spin trapping of biological nitric oxide. J. Chromatogr. B. Analyt. Technol. Biomed. Life Sci., 851(1-2), 12-20.

Koncz, S., Horváth, E.J. (1996). Ipriflavone metabolite-III inhibits LPS-induced nitric oxide release from RAW-264.7 cells. Acta Physiol. Hung., 84(3), 223-228.

Liu, Z., Song, Y., Zhang, X., Liu, Z., Zhang, W., Mao, W., Wang, W., Cui, W., Zhang, X., Jia, X., Li, N., Han, C., Liu, C. (2005). Effects of trans- resveratrol on hypertension-induced cardiac hypertrophy using the partially nephrectomized rat model. Clin. Exp. Pharmacol. Physiol., 32(12), 1049-1054.

Manna, S.K., Mukhopadhyay, A., Aggarwal, B.B. (2000). Resveratrol suppresses TNF-induced activation of nuclear transcription factors NF-kappa $\mathrm{B}$, activator protein-1, and apoptosis: Potential role of reactive oxygen intermediates and lipid peroxidation. J. Immunol., 164(12), 6509-6519.

Olszanecki, R., Gebska, A., Kozlovski, V.I., Gryglewski, R.J. (2002). Flavonoids and nitric oxide synthase. J. Physiol. Pharmacol., 53(4 Pt. 1), 571-584.

Orallo, F., Alvarez, E., Camiña, M., Leiro, J.M., Gómez, E., Fernández, P. (2002). The possible implication of trans-Resveratrol in the cardioprotective effects of long-term moderate wine consumption. Mol. Pharmacol., 61(2), 294-302.

Salerno, J.C., Ghosh, D.K. (2009). Space, time and nitric oxide - neuronal nitric oxide synthase generates signal pulses. FEBS J., 276(22), 66776688.

Sarkar, F.H., Li, Y. (2004). Cell signaling pathways altered by natural chemopreventive agents. Mutat. Res., 555(1-2), 53-64.

Seaver, B., Smith, J.R. (2004). Inhibition of COX isoforms by nutraceuticals. J. Herb. Pharmacother., 4(2), 11-18.

Sies, H., Schewe, T., Heiss, C., Kelm, M. (2005). Cocoa polyphenols and inflammatory mediators. Amer. J. Clin. Nutr., 81(1 Suppl), 304S-312S.

Singh, R., Singh, B., Singh, S., Kumar, N., Kumar, S., Arora, S. (2008). Anti-free radical activities of kaempferol isolated from Acacia nilotica (L.) Willd. Ex. Del. Toxicol in Vitro., 22(8), 1965-1970.

Sjakste, N., Andrianov, V.G., Boucher, J.L., Shestakova, I., Baumane, L., Dzintare, M., Meirena, D., Kalvinsh, I. (2007). Paradoxical effects of two oximes on nitric oxide production by purified NO synthases, in cell culture and in animals. Nitric Oxide., 17 (3-4), 107-114.

Sjakste, N., Baumane, L., Meirena, D., Lauberte, L., Dzintare, M., Kalvinsh, I. (1999). Drastic increase in nitric oxide content in rat brain under halothane anaesthesia, revealed by EPR method. Biochem Pharmacol., 58, 1955-1959.

Sjakste, N., Baumane, L., Meirena, D., Lauberte, L., Dzintare, M., Kalvinsh, I. (1999). Nitric oxide and anaesthetic action mechanisms, with focus on halothane. Proc. Latv. Acad. Sci., Sect B, 53(6), 301-307.

Sjakste, N., Kleschyov, A.L., Boucher, J.L., Baumane, L., Dzintare, M., Meirena, D., Sjakste, J., Sydow, K., Münzel, T., Kalvinsh, I. (2004). Endothelium- and nitric oxide-dependent vasorelaxing activities of gammabutyrobetaine esters: Possible link to the antiischemic activities of mildronate. Eur. J. Pharmacol., 495, 67-73.

Sjakste, N., Sjakste, J., Boucher, J.L., Baumane, L., Sjakste, T., Dzintare, M., Meirena, D., Sharipova, J., Kalvinsh, I. (2005). Putative role of nitric oxide synthase isoforms in the changes of nitric oxide concentration in rat brain cortex and cerebellum following sevoflurane and isoflurane anaesthesia. Eur. J. Pharmacol., 513, 193-205.

Soliman, K.F., Mazzio, E.A. (1998). In vitro attenuation of nitric oxide production in C6 astrocyte cell culture by various dietary compounds. Proc. Soc. Exp. Biol. Med., 218(4), 390-397.

Wadsworth, T.L., Koop, D.R. (1999) Effects of the wine polyphenolics quercetin and resveratrol on pro-inflammatory cytokine expression in RAW 264.7 macrophages. Biochem Pharmacol., 57(8), 941-949.

Wallerath, T., Li., H., Godtel-Ambrust, U., Schwarz, P.M., Forstermann, U. (2005). A blend of polyphenolic compounds explains the stimulatory effect of red wine on human endothelial NO synthase. Nitric Oxide., 12(2), 97-104

Сьяксте Н.И., Дзинтаре М.Я., Баумане Л.Х., Мейрена Д.В., Ляуберте Л.Я., Калвиньш И.Я. (2001). Роль оксида азота (NO) в механизме действия средств для наркоза [Role of nitric oxide (NO) in the mechanism of anesthetic action]. Анестезиология и реаниматология., 3, 61-65 (in Russian). 

IETEKMĒ: SALİDZINOŠS PĒTİJUMS

Augos sintezētie dabīgie polifenolu savienojumi, uzṇemti kā zāles vai pārtikas sastāvā, ietekmē vairākus šūnu signālpārneses cel̦us, ieskaitot arī slāpekḷa oksīda (NO) sintāzes (NOS) ekspresijas ceḷu. Šo savienojumu iedarbība uz NO produkciju in vivo ne vienmēr sakrīt ar to inhibējošo ietekmi uz NOS, ko novēro eksperimentos ar šūnu kultūrām. Šī pētījuma mērkiis bija izpētīt resveratrola, ellagskābes un ipriflavona iedarbību uz NO produkciju žurku audos, izmantojot elektronparamagnētiskās rezonanses (EPR) spektroskopiju. Visi pētījumā iekḷautie savienojumi ir zināmi kā inducējamās slāpekḷa oksīda sintāzes (iNOS) ekspresijas inhibitori. Tomēr vienīgi ellagskābe spēja samazināt NO produkciju un tikai vienā orgānā - intaktu žurku liesā. Ipriflavons un resveratrols pat pastiprināja lipopolisaharīda (LPS) izsaukto NO produkciju. Ipriflavons pastiprināja NO produkciju smadzeņu garozā, smadzenītēs, aknās, sirdī, nierēs, asinīs, plaušās un skeleta muskuḷos. Resveratrols izsauca līdzīgu efektu visos augstāk minētajos orgānos, izņemot nieres, plaušas un muskuḷus. Kopumā mūsu dati liecina, ka dabīgo savienojumu iedarbību uz NO līmeni audos nav iespējams paredzēt, pamatojoties uz datiem par tā iedarbību uz NOS ekspresiju. Šis secinājums pasvītro tiešu NO satura mērījumu nepieciešamību audos. 